\title{
A COMPARATIVE ANALYSIS OF SILENT PAUSES AND RATE OF ARTICULATION IN THE DISCOURSE OF SITCOM ${ }^{1}$
}

\author{
Magdaléna Bilá
}

\begin{abstract}
The objective of the present paper is to provide the results of follow-up research into conversations in an episode of the sitcom Friends. The study is based on two selected phonetic features: ungrammatical silent pauses and rate of articulation, in order to substantiate whether these features contribute to the spokenness of the film dialogue in the focal sitcom and to explore in what manner these features are produced in the original version and the dubbed version (Slovak).
\end{abstract}

\section{Key words}

within-speaker silent pause, rate of articulation, dubbing, spokenness, writteness

\section{Introduction}

The aim of the present paper is to introduce the results of research into dialogue in an episode of the sitcom Friends. The investigation is targeted at two selected phonetic features: ungrammatical silent pauses and rate of articulation, in order to discover whether these features contribute to the spokenness of the film dialogue in the focal sitcom. Another objective of the analysis is to compare in what manner ungrammatical silent pauses and rate of articulation are realized in the original version and the dubbed version (Slovak).

A number of researchers have been attracted by exploring sitcom conversation either as an object itself or by comparing its linguistic features to features of spontaneous conversation. Sitcom dialogue writers aim at representing the everyday exchanges people engage in; in other words, they strive for naturalness. Sitcoms are typified by a complex procedure of planning and production and, as a rule, a number of writers participate in the script and dialogue writing, hence they are characterized by multiple authorship (e.g. Mills 2009, Quaglio 2009, Romero Fresco 2009).

Sitcom conversations enable the viewer to recognize the fictional location, time and characters. Conversations help viewers comprehend the characters' personal traits and their motivation to act in a certain manner. Therefore, script writers disperse a variety of idiosyncrasies (such as slang, dialect expressions, catchphrases, etc.) throughout the characters' speech. Further, script writers use dialogues to guide the viewer and relate to the audience through the characters' conversation (cf. Quaglio 2009). 
Spontaneous conversations exhibit a number of conventional features which at the phonic level include pause phenomena and emphatic intonation contours (Kačmárová 2006); at the lexical level, use of clichés and vague expressions, incidence of interjections, intensifiers, colloquial, idiomatic and slang expressions, preference for monosyllabic words and a considerable degree of redundancy; features falling within phonetic and lexical levels, such as false starts, repetitions and self-corrections; features of the syntactic level, such as vague sentence boundaries, syntactic incompleteness, preference for paratactic structures and locating comment-clauses in end-position (Quian 2004: 152-160). These features are collectively referred to as 'performance phenomena'. (cf. Biber et al. 1999) or features of 'normal non-fluency' (Quian 2004).

Romero Fresco (2009) compared the conversations in Friends with natural conversations and revealed that unlike in spontaneous speech, at the phonic level sitcom conversations exhibit correct standard pronunciation, careful articulation, and avoidance of inapt pauses, prosodic vagueness as well as of unnecessary occurrence of simultaneous speech of several characters. At morphological and syntactic levels sitcom conversations manifest a lesser degree of syntactic incompleteness, fragmentation and divergence from norms than spontaneous dialogues, and, finally, at the discourse level, they exhibit avoidance of excessive alteration of topics (Romero Fresco 2009).

Based on Biber et al.'s study of English register variation (and Dimension 1 differentiating between involved versus informational production), Quaglio (2009: 140-149) conducted a multifaceted comparative analysis of two corpora - Friends and natural conversation. The analysis yielded similar scores (34.4 on D1 for Friends and 35.3 for face-to-face conversation), which supports the claim that sitcom conversation resembles natural conversation ${ }^{2}$. Further analysis of the use of vague linguistic devices revealed a minor divergence illustrating a higher occurrence of vague language in natural conversation than in Friends. Quaglio (2009) explains this difference by the fact that the 'real interlocutors' in a sitcom conversation are not characters themselves, rather they are script and dialogue writers and TV viewers who must share a common ground in order to be able to follow the conversations. Moreover, Friends consistently presented higher frequencies of the majority of features of involved registers (out of the 35 analyzed features, 31 exhibited a higher frequency in Friends). Quaglio's comparative analysis, however, unveiled considerable differences in the two registers in their extent of narrativeness (expressed through past tense verbs, third-person pronouns, perfect aspect, and public verbs). Although the analyzed corpora are both typical for their low degrees of narrativeness when compared to characteristically narrative registers (fiction), the natural conversations contained 
a higher frequency of narrative portions than conversations in Friends, this disparity being attributable to the discourse immediacy of Friends conversations. Some of the potential differences between Friends and natural conversation seem to stem from either limitations imposed by the televised medium, the television network, or the type of this specific sitcom. Another factor that may be at play here, Quaglio notes, is humor that may have exercised influence on the selection of particular linguistic devices. Quaglio's study demonstrates that Friends shares typical linguistic features with involved registers, such as face-to-face conversation. Nevertheless, this finding does not show that the scripted language of Friends is identical with natural conversation (Quaglio 2009: 140-149).

Earlier research (Bilá \& Kačmárová, forthcoming) on an episode of Friends investigated the position of sitcom discourse on a virtual scale of 'spokenness writtenness'. The starting point of the investigation was the treatment of the target discourse as seeking to give an impression of spontaneous speech, designed to be acted out as if it was not premeditated and written in advance. The exploration comprised two sub-analyses: the former one included a description of speech (as opposed to writing) based on Crystal's (Crystal \& Davy 1969) taxonomy of spoken mode features; speech being time-bound, spontaneous, face-to-face, socially interactive, loosely structured, immediately revisable, and prosodically rich. Each feature was detected in the target discourse functioning in a specific manner - altogether yielding the characteristics of pre-scripted text to be read out and performed. The latter analysis targeted the features of the spoken mode in the sitcom in question and was based on Mistrík's (1997) treatment of spontaneous speech typified by vocality, conversationality, familiarity, contextuality and expressiveness. The findings of this analysis showed that the discourse of the target sitcom represents verbal performance that is observable in spontaneous speech. With reference to vocality, the investigation of pause duration and pausetonic-stress interrelation indicated potential similarity of the focal discourse with a publicistic/journalistic style, in other words the similarity of the sitcom discourse to the text to be read.

\section{Analysis of silent pauses ${ }^{3}$ in the English original and the Slovak dubbed version}

Pauses are of major importance for both the speaker and hearer. Predictable or grammatical pauses (Silverman et al. 1992) are responsible for segmenting the flow of speech into semantic portions and drawing a listener's attention to the most important components of an utterance. Such pauses as a rule occur at syntactic constituent boundaries and are of longer duration (above $200 \mathrm{~ms}$ ) whereas the pauses of physiological origin (respiratory pauses) are generally 
of shorter duration (Zellner 1994). Neurolinguists claim that the frequency, distribution and duration of pauses are controlled by a neurological device through synchronising the stimuli transmitted to articulatory muscles (ibid.). This hypothesis has been supported by further research study conducted by Ramanarayanan and Bresch (2009). By analysing the speed of articulators at and around grammatical and ungrammatical pauses in spontaneous speech through real-time magnetic resonance imaging, they found that grammatical pauses have a significant fall in speed at the pause itself (unlike ungrammatical pauses). This supports their hypothesis that grammatical pauses are controlled by a central cognitive device.

In addition to physiological needs and syntactic structuring, the distribution and frequency of pauses depend on several other factors. Speech activity being a motor activity has an individual character and thus the occurrence of pauses in it is, to a large extent, dependent on an individual speaker (e.g. weak respiration, low muscle tone and slow rate of articulation will generate a higher frequency of pauses whereas fast articulation and good respiratory capacity will reduce their number). In addition to individual constraints, pauses can also be ascribed to temporal limitations and situational constraints (e.g. speaking in a stressful or emotional situation) (Zellner 1994).

Ungrammatical (e.g. word search) pauses tend to occur in spontaneous speech since planning of an utterance frequently lags behind the delivery. These pauses together with further features of impromptu speech (such as false starts, filled pauses etc.) are regarded as "common occurrences" and thus termed as "normal non-fluency" or "performance phenomena" (Zellner 1994, Biber et al. 1999, Quian 2004). "Ungrammatical pauses may be reinterpreted as merely being located at more embedded levels of bracketing in a syntactic structure than grammatical pauses" (Silverman et al. 1992, their italics).

It was hypothesised that ungrammatical pauses in the sitcom conversations would be utilised and thus manifest spokenness.

The data were extracted from an episode of the sitcom Friends, namely "The One Where No One Proposes", part one, season nine. In measuring the intra-sentential pauses, Steinberg software (program Wave Lab 6) was used. In each language version intra-sentential pauses in forty-six/fifty utterances were measured (a total of 453 pauses), experimental measurements being supported by perceptual checks. The measurements and subsequent evaluations were based on the linguistic typology of pauses as introduced by Sabol and Zimmermann (1984: 227-228). Their detailed typology seemed to be well suited to the data since it was hypothesized that pauses of extremely short duration would be prevalent in the research material. 
The following tables illustrate the frequencies of individual pause types and the total pause time in the two language versions (Bilá et al. 2011: 38-82).

\begin{tabular}{|l|c|c|}
\hline Pause type & $\begin{array}{c}\text { Number of } \\
\text { pauses } \\
\text { in English }\end{array}$ & $\begin{array}{c}\text { Number of } \\
\text { pauses } \\
\text { in Slovak }\end{array}$ \\
\hline Zero pause or extremely short pause $(\mathrm{ES}, \leq 50 \mathrm{~ms})$ & 204 & 148 \\
\hline Very short pause $(\mathrm{VS}, 50 \mathrm{~ms}-\leq 100 \mathrm{~ms})$ & 51 & 30 \\
\hline Short pause (S, $100 \mathrm{~ms}-\leq 300 \mathrm{~ms})$ & 10 & 0 \\
\hline Normal or optimal pause $(\mathrm{O}, 300 \mathrm{~ms}-\leq 1350 \mathrm{~ms})$ & 6 & 3 \\
\hline Long pause $(\mathrm{L}, 1350 \mathrm{~ms}-\leq 2200 \mathrm{~ms})$ & 1 & 0 \\
\hline Very long pause $(\mathrm{VL}, 2200 \mathrm{~ms}-\leq 2800 \mathrm{~ms})$ & 0 & 0 \\
\hline Extremely long pause $(\mathrm{EL}, \geq 2800 \mathrm{~ms})$ & 0 & 0 \\
\hline TOTAL & $\mathbf{2 7 2}$ & $\mathbf{1 8 1}$ \\
\hline
\end{tabular}

Table 1: Pause types and their numbers in the English and Slovak versions

\begin{tabular}{|c|c|}
\hline Language & $\begin{array}{c}\text { Total pause duration } \\
\text { in } \mathbf{~ m s}\end{array}$ \\
\hline English version & $\mathbf{1 5 , 5 4 7}$ \\
\hline Slovak version & $\mathbf{8 , 8 6 2}$ \\
\hline
\end{tabular}

Table 2: Total pause time (in ms) in the English and Slovak versions

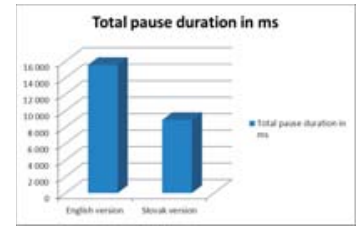

Graph 1: Total pause duration (in $\mathrm{ms}$ ) in the English and Slovak versions

The data were further processed by means of descriptive statistics in which the highest frequency was observed in extremely short pauses (ES). Short pauses (S) manifested a high frequency in the English version and were absent in the Slovak version and very short pauses (VS) exhibited a higher frequency in the English version. Normal/optimal pauses (O) showed a considerably low frequency in both language versions and longer duration pauses were completely absent in both language versions. The shortest pause durations detected in both language versions were almost identical (21 ms in the English version and $22 \mathrm{~ms}$ in the Slovak one).

Statistics on data indicated that the duration of a sequence is not automatically dependent on the maximum total pause duration, meaning that the longest pause durations in the two language versions were different. 


\begin{tabular}{|c|c|c|c|c|c|c|c|c|c|c|c|}
\hline English & & Paus & type & & Sum & Slovak & & Pat & type & & Sum \\
\hline & ES & $\mathbf{S}$ & VS & $\mathbf{O}$ & & & ES & $\mathbf{S}$ & VS & $\mathbf{O}$ & \\
\hline Min & 21 & 102 & 51 & 524 & 0 & Min & 22 & 0 & 51 & 372 & 22 \\
\hline Max & 309 & 299 & 351 & 731 & 1124 & Max & 232 & 0 & 213 & 678 & 880 \\
\hline Average & 129 & 180 & 123 & 634 & 342,4 & Average & 118 & 0 & 106 & 546 & 232 \\
\hline Med & 120 & 163 & 90 & 634 & 254 & Med & 113 & $\mathbf{0}$ & 84 & 586 & 184 \\
\hline
\end{tabular}

Table 4: Total durations of all pauses; minimal, maximal and average durations; median of four pause types (extremely short - ES, very short - VS, short - S and normal/optimal - O pause) in the two language versions

The following table illustrates the average durations, minimal, maximal and median values of the two most frequently occurring pause types (extremely short - ES and very short pause - VS) (cf. Bilá et al. 2011: 38-82):

\begin{tabular}{|c|c|c|c|c|c|}
\hline English & ES & VS & Slovak & ES & VS \\
\hline Min & $\mathbf{8 , 3 3}$ & 58 & Min & 19 & 58 \\
\hline Max & $\mathbf{3 8 , 5}$ & 81 & Max & 42,33 & 86 \\
\hline Average & 23,06 & 68,13 & Average & 30,12 & 67,27 \\
\hline Med & 24,38 & 66,34 & Med & 29,33 & $\mathbf{6 5 , 0 9}$ \\
\hline
\end{tabular}

Table 5: Average durations, minimal, maximal and median of the two most frequently occurring pause types (extremely short - ES and very short pause - VS) in the two language versions

Further inductive statistics were applied, specifically the Kruskal-Wallis ${ }^{4}$ one-way analysis of variance by ranks, which is a non-parametric method for testing whether the given samples originate from the same distribution (cf. Bilá et al. 2011: 38-82). A comparison of the mean durations of the two most frequently occurring pause types (extremely short - ES and very short - VS) was made and a statistically significant difference (at the significance level $\alpha=0.01$ ) between the two language versions in the mean duration of extremely short pause was detected (as illustrated by Table 6). The comparison of the mean durations of very short pauses, however, did not reveal a statistically significant difference (at the significance level $\alpha=0.01$ ) between the two language versions. 


\begin{tabular}{|l|l|}
\hline Dependent variable & $\begin{array}{l}\text { Extremely short pause }(\mathrm{ES}) \\
\text { Kruskal-Wallis test: } \mathrm{H}(2, \mathrm{~N}=103)=21,46358 \mathrm{p}=.0000 \\
\text { Slovak }\end{array}$ \\
\hline English & 0,000022 \\
\hline Slovak & 0,000022 \\
\hline
\end{tabular}

Table 6: The Kruskal-Wallis one-way analysis of variance by ranks for extremely short pause (ES) in the two language versions

With regard to the difference and/or similarity in the utilisation and occurrence of pauses in the original version and the dubbed version, several differences could be spotted, specifically in the total number of pauses (272 in the English version and 181 in the dubbed version), in the total pause duration time (15,547 $\mathrm{ms}$ in the English version and 8,862 $\mathrm{ms}$ in the dubbed version). A high prevalence of short duration pauses (extremely short and very short) typical for spontaneous speech (cf. Sabol \& Zimmermann 1984, Zellner 1994) was also found in the conversations of the investigated episode of Friends and thus it was possible to illustrate that this phonetic feature contributed to the spokenness of the given sitcom conversations.

\subsection{Analysis of ungrammatical silent pauses in the English original and the Slovak dubbed version}

In the present analysis the pauses are divided into grammatical and ungrammatical. Only pauses of duration of or above $200 \mathrm{~ms}$ are considered since the pauses of or below this duration are generally regarded as junctural phenomena or as pauses of physiological origin - respiratory pauses (Silverman et al. 1992). As illustrated in Table 7 below, merely ten pauses in the original version and three pauses in the dubbed version meet the criteria.

\begin{tabular}{|l|c|c|}
\hline Pause type & $\begin{array}{c}\text { Number of pauses in } \\
\text { English }\end{array}$ & $\begin{array}{c}\text { Number of pauses in } \\
\text { Slovak }\end{array}$ \\
\hline Grammatical of $\leq 200 \mathrm{~ms}$ & 5 & 1 \\
\hline Ungrammatical of $\leq 200 \mathrm{~ms}$ & 5 & 3 \\
\hline
\end{tabular}

Table 7: Grammatical (light grey cells) and ungrammatical pauses (dark grey cells) in the English and Slovak conversations

Interestingly, two hesitation pauses can be detected in both language versions in the identical sequence and in the same location, their durations being $730 \mathrm{~ms}$ and $588 \mathrm{~ms}$ in the English version and $678 \mathrm{~ms}$ and $372 \mathrm{~ms}$ in the Slovak one. 
The following table juxtaposes grammatical pauses in the English version and their equivalents in the Slovak version. In the dubbed Slovak version in all the dialogues extremely short pauses occur, which may be explained by the typological differences between the English and Slovak languages (more articulation time needed in the Slovak version owing to Slovak being an inflectional language).

\begin{tabular}{|c|c|c|}
\hline Pause type & English original & Slovak dubbed version \\
\hline Grammatical & $299 \mathrm{~ms}$ & no equivalent (ES pause used) \\
\hline Grammatical & $731 \mathrm{~ms}$ & no equivalent (missing sequence) \\
\hline Grammatical & $237 \mathrm{~ms}$ & no equivalent (ES pause used) \\
\hline Grammatical & $563 \mathrm{~ms}$ & no equivalent (ES pause used) \\
\hline Grammatical & $285 \mathrm{~ms}$ & no equivalent (ES pause used) \\
\hline
\end{tabular}

Table 8: Grammatical pauses in the English original and their equivalents in the Slovak conversations

The following table juxtaposes ungrammatical pauses in the English version and their equivalents in the Slovak version. In the dubbed Slovak version two pauses of shorter duration occur and the remaining three ungrammatical pauses have zero pause equivalents in the Slovak version, which may likewise be attributable to the typological differences between the English and Slovak languages.

\begin{tabular}{|c|c|c|}
\hline Pause type & English original & Slovak dubbed version \\
\hline Ungrammatical & $262 \mathrm{~ms}$ & no equivalent (ES pause used) \\
\hline Ungrammatical & $730 \mathrm{~ms}$ & $678 \mathrm{~ms}$ \\
\hline Ungrammatical & $588 \mathrm{~ms}$ & $372 \mathrm{~ms}$ \\
\hline Ungrammatical & $218 \mathrm{~ms}$ & no equivalent (ES pause used) \\
\hline Ungrammatical & $679 \mathrm{~ms}$ & no equivalent (ES pause used) \\
\hline
\end{tabular}

Table 9: Ungrammatical pauses in the English original and their equivalents in the Slovak conversations

\subsection{Analysis of the rate of articulation in the original and the dubbed versions}

In the following table the total syllable count and the total articulation time (time of extract minus pause time) are given. Subsequently, the rate of articulation (RA, number of syllables articulated per second) in both language versions is calculated and compared. The data are also illustrated in the graphs. 


\begin{tabular}{|c|c|}
\hline English original & Slovak dubbed version \\
\hline 447 syllables & 534 syllables \\
\hline 110.53 s total articulation time & $177.38 \mathrm{~s}$ total articulation time \\
\hline 4.04 syllables per second & 3.01 syllables per second \\
\hline
\end{tabular}

Table 10: Total syllable count, total articulation time and rate of articulation in English and Slova versions

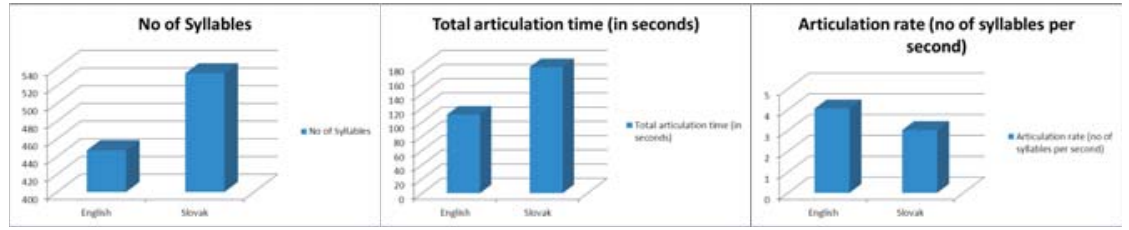

Graph 2: Total syllable count, total articulation time (time of extract minus pause time) and rate of articulation (number of syllables per second) in the English original and the Slovak dubbed versions

Research into the rate of articulation in English conducted by Jacewicz et al. (2009) reveals the following values of the overall mean articulation rate: in read sentences $3.40 \mathrm{syll} / \mathrm{s}$ (s.d. $=0.42$ ) and in spontaneous talk: $5.12 \mathrm{syll} / \mathrm{s}$ $($ s.d. $=0.59)$. The data in the above-given tables and graphs show values which fall between these two values.

Research into the rate of articulation and information load in Slovak conducted by Sabol (1976) revealed the following values of the overall mean articulation rate: in spontaneous talk $4.05 \mathrm{syll} / \mathrm{s}$, in publicistic/journalistic style $3.92 \mathrm{syll} / \mathrm{s}$ and in read literary texts $3.95 \mathrm{syll} / \mathrm{s}$. Further research into the rate of articulation in media communication and its perception conducted by Smoláková (2010) revealed an increase of RA of 2.49 syll/s and provided the following categorization: slow RA up to $4.1 \mathrm{syll} / \mathrm{s}$; rather slow $4.1-4.8 \mathrm{syll} / \mathrm{s}$; appropriate $4.8-6.8 \mathrm{syll} / \mathrm{s}$; rather fast $6.8-8.2 \mathrm{syll} / \mathrm{s}$; and fast $8.2-8.6 \mathrm{syll} / \mathrm{s}$. The results given in Table 10 can be interpreted as indicating slow RA, i.e. values more typical for read texts in media communication in a journalistic/publicistic style.

Regarding the differences between the original and dubbed version, these may be attributable to the specific features of dubbing as well as to the typological differences between the two languages in question. The chief aim of the dubbing is to provide an authentic experience akin to the effect achieved by the original (Makarian 2009). Hence the challenges of dubbing result from the necessity of accounting for the meaning of spoken utterances and the original actors' performance. What is more, it is imperative that the original 
and the dubbed versions be synchronised (Makarian 2009), the synchronisation including (Paquin 1998) phonetic (the adjustment of the original actors' and dubbing actors' articulatory movements, notably lip movements), semantic (the equivalence of meaning of the original and dubbed text) and dramatic synchronisation (achieving 'realism').

\section{Results and discussion}

The investigation of the spokenness - writtenness scale in relation to the discourse sitcom appears to support earlier findings, namely that sitcom conversations represent a discourse exhibiting features of both spokenness and writtenness, that is to say, pre-written text to be acted out as if not written in advance (cf. Quaglio 2009, Romero Fresco 2009, Bilá \& Kačmárová, forthcoming).

The results of the present research into ungrammatical pauses in the original and dubbed versions of the film conversations illustrate differences in the total number of this pause type in the original version (10) and in the dubbed version (3), identical utilisation and occurrence of two hesitation pauses, prevalence of extremely short pauses in the dubbed version and zero pause equivalents of three ungrammatical pauses in the dubbed version.

The results of the present research into the rate of articulation support the earlier findings that sitcom conversations represent a discourse combining the features of both spokenness and writtenness as the RA values tend to be lower than those for spontaneous dialogues but higher than those more typical for read texts.

The results of the present research into the rate of articulation in the original and the dubbed version reveal differences in the total articulation time, the total number of articulated syllables as well as the resulting rate of articulation. These findings appear to be ascribable to several factors: firstly, to the issue of synchronization (phonetic synchronisation, especially synchronization of lip movements and semantic synchronisation); secondly, to the typical feature of the English colloquial style - the prevalence of and preference for short, monosyllabic words; and thirdly to the typological differences between the two languages in question (an analytical language versus a synthetic language, in other words, the use of structure words in the English language and the addition of grammatical suffixes to the word stems in the Slovak language). The last two factors appear to be especially evidenced by the total syllable count. 


\section{Endnotes}

1 This publication is the result of the project implementation: Retrofitting and Extension of the Center of Excellence for Linguaculturology, Translation and Interpreting supported by the Research and Development Operational Programme funded by the ERDF. ITMS project code: 26220120044; contract number: 031/2009/2.1/OPVaV.

2 Dimension 1 represents a continuum extending from extremely involved (interactive) to extremely informational registers. The former registers, like face-to-face conversation, are typified by high incidence of features comprising private/mental verbs, that-deletion, contractions, present-tense verbs, and first- and second-person personal pronouns. Conversely, highly informational registers tend to manifest high frequencies of nouns, nominalizations, prepositions, attributive adjectives, and agent-less passive constructions. The analysis in question manifested the similarity in the core linguistic features with involved registers (Quaglio 2009: 140).

3 Silent pauses in this study are understood as "within-speaker acoustic silences" (Heldner \& Edlund 2010).

4 Kruskal-Wallis one-way analysis of variance by ranks (named after William Kruskal and W. Allen Wallis) is a non-parametric method for testing whether samples originate from the same distribution. It is used for comparing more than two samples that are independent, or not related (http://en.wikipedia.org/wiki/Kruskal\%E2\%80\%93Wallis_one-way_analysis_of_variance). The test applied is a component of the Statistica 12 software purchased by the Prešov University, included in the package available at: http://www.unipo.sk/cvtpu/helpdesk/stat12.

\section{References}

Biber, D., Johansson, S., Leech, G., Conrad, S. and Finegan, E. (1999) Longman Grammar of Spoken and Written English. London: Longman.

Bilá, M., Džambová, A. and Kačmárová, A. (2011) Fonetické, syntaktické a pragmatické aspekty hovoreného prejavu. (Sonda do diskurzu sitkomu v angličtine, v nemčine a $v$ slovenčine) Prešov: Prešovská univerzita v Prešove, Filozofická fakulta. AFPh UP $321 / 402$.

Bilá, M. and Kačmárová, A. (forthcoming) 'On the mode of sitcom discourse.' Oita Text Forum. Oita University, 700 Dannoharu Oita-shi 870-1192, Japan.

Braun, A. and Oba, R. (2007) 'Speaking tempo in emotional speech - A cross-cultural study using dubbed speech.' Online proceedings. Online document. 7 May 2014 $<$ www.dfki.de/paraling07/programme $>$

Critical review of the sitcom PRIATELIA. Online document. 7 May $2014<$ http://citanie. madness.sk/view-84.php\#ixzz1TFlqcPgT>

Crystal, D. and Davy, D. (1969) Investigating English Style. London: Longman.

Chaume, F. (2004) 'Film studies and translation studies. Two disciplines at stake in audiovisual translation.' Meta Translators' Journal. 1/2004. 12-24. Online document. 7 May $2014<$ http://www.erudit.org/revue/meta/2004/v49/n1/009016ar.pdf>

Griffith, R. (1991) 'Pausological research in an L2 context: A rationale, and review of selected studies.' Applied Linguistics, 12, 4/1991, 345-364.

Heldner, M. and Edlund, J. (2010) 'Pauses, gaps and overlaps in conversations.' Journal of Phonetics, 38, 555-568.

Jacewicz, E., Fox, R. A., O'Neill, C. and Salmons, J. (2009) 'Articulation rate across dialect, age, and gender.' Online document. 7 May $2014<$ http://www.ncbi.nlm.nih. gov/ pmc/articles/PMC2790192/pdf/nihms124778.pdf>

Kačmárová, A. (2006) On Conveying Strong Judgments in Conversational English. Prešov: Prešovská univerzita v Prešove, Filozofická fakulta. 
Koreman, J. (2005) 'Perceived speech rate: The effects of articulation rate and speaking style in spontaneous speech.' Online document. 7 May $2014<$ http://www.hf.ntnu.no/ isk/ koreman/Publications/2006/JASA PercRate.pdf $>$

Krause, J. C. and Braida, L. D. 'Investigating alternative forms of clear speech: The effects of speaking rate and speaking mode on intelligibility.' Online document. 7 May $2014<$ http://www.ncbi.nlm.nih.gov/pubmed/12430828>

Kraviarová, M. (2012) 'Masmediálne štúdiá z pohl'adu akusticko-auditívnej komunikácie.' In: Matúšová, J., Baluchová, B. and Benková, B. (eds) Budúcnost’ médií. Bratislava: Fakulta masmédií Paneurópskej vysokej školy v Bratislave, Inštitút mediológie a politológie Mediatika. 334-353. Online document. 7 May $2014<$ http://www. paneurouni.com/files/sk/fm/aktuality/bm_2012_zbornik_print.pdf >

Litavcová, E. and Butoracová-Šindleryová, I. (2010) 'Application of log-linear analysis in marketing research.' Online document. 7 May $2014<$ http://mpra.ub.uni-muenchen. de/20260/>

Majherová, M. (2000) 'Využitie Excelu pri niektorých neparametrických štatistických testoch.' Informatika a algoritmy 2000: Zborník z medzinárodnej konferencie konanej 7.-8. septembra 2000 v Prešove. Prešov: Fakulta výrobných technológií Technickej Univerzity v Košiciach so sídlom v Prešove. 235-238.

Makarian, G. (2005) Dabing: Teória, realizácia, zvukové majstrovstvo. Bratislava: Ústav hudobnej vedy SAV.

Mills, B. (2009) The Sitcom. Edinburgh: Edinburgh University Press.

Mitrová, A., Sabol, J., Slančová, D. and Zimmermann, J. (2006) 'Realizácia suprasegmentálnych javov v reči orientovanej na diet’a.' Slovenská reč. 71/ I, 3-17.

Mistrík, J. (1997) Štylistika. Bratislava: SPN.

Moláková, K. (2007) ‘Soap opera a sitcom v kontexte masmediálnej komunikácie.’ Online document. 7 May $2014<$ http://ftf.vsmu.sk/files/Molakova_SoapOperaUryvok\%20. pdf $>$

Paquin, R. (1998) 'Translating for the audio-visual in a bilingual country.' In: Gambier, Y. (ed.) Translating for the Media, Papers from the International Conference Languages and the media (Berlin, November 22-23, 1996), University of Turku, Centre for Translation and Interpreting.

Quaglio, P. (2009) Television Dialogue. The Sitcom Friends vs. Natural Conversation. Amsterdam and Philadelphia: John Benjamins.

Ramanarayanan, V. and Bresch, E. (2009) 'Analysis of pausing behavior in spontaneous speech using real-time magnetic resonance imaging of articulation.' EL160 J. Acoust. Soc. Am. 126 5, November 2009. Online document. 7 May $2014<$ http://www.ncbi. nlm.nih.gov/ pmc/articles/PMC2776778/>

Romero Fresco, P. (2009) 'A corpus-based study on the naturalness of the Spanish dubbing language: The analysis of discourse markers in the dubbed translation of friends.' Online document. 7 May $2014<$ http://www.ros.hw.ac.uk/bitstream/10399/2237/1/ RomeroFrescoP_0209_sml.pdf>

Silverman, K. E. A., Blaauw, E., Spitz, J. and Pitrelli, J. F. (1992) Towards Using Prosody in Speech Recognition/Understanding. Online document. 7 May 2014 http://acl.ldc. upenn.edu/ H/H92/H92-1088.pdf

Slunčík, V. (2010) 'Sitcom: Vývoj a realizace.' Online document. 7 May $2014<$ http:// www.ereading.cz/nakladatele/data/ebooks/848_preview.pdf> 
Sabol, J. and Zimmermann, J. (1984) 'Komunikačná hodnota pauzy.' In: Úloha reči a hudby v životním prostředí. XXIII. Akustická conference. České Budějovice: ČSVTS 1984, 225-229.

Sabol, J. (2006) 'Pauza a dôraz.' In: Sabol, J., Bónová, I. and Sokolová, M. (eds) Kultúra hovoreného prejavu. Prešov: Acta Facultatis Philosophicae Universitatis Prešoviensis. Prešovská univerzita v Prešove, Filozofická fakulta. 171-172.

Sabol, J. and Zimmermann, J. (1984) 'Komunikačná hodnota pauzy.' Úloha řeči a hudby $v$ životním prostředí. XXIII. Akustická conference. České Budějovice: ČSVTS 1984, 225-229.

Sabol, J. (1976) 'Spolupôsobenie pauzy a tempa reči.' Kultúra slova, 8/0, 263-266.

Smoláková, V. (2010) 'Tempo reči mediálnych pracovníkov. Jazyk a kultúra. 1/2010. Online document. 7 May 2014. <http://www.ff.unipo.sk/jak/cislo1.html>

Viola, I. C. and Madureira, S. (2008) 'The roles of pause in speech expression.' Online document. 7 May $2014<$ http://aune.lpl.univ-aix.fr/ sprosig/sp2008/papers/id188. pdf $>$

Quain, Y. (1991) Stylistics: A Coursebook for Chinese EFL Students. Beijing: Beijing Normal University Press.

Yang, Li-chiung (2004) 'Duration and pauses as cues to discourse boundaries in speech.' Speech Prosody. Nara, Japan. 23-26.

Zellner, B. (1994) 'Pauses and the temporal structure of speech.' In: Keller, E. (ed.) Fundamentals of Speech Synthesis and Speech Recognition. Chichester: John Wiley. 41-62.

Functions of Dialogue in Narrative film. Online document. 7 May $2014<$ http://www. filmreference.com/encyclopedia/Criticism-Ideology/Dialogue-FUNCTIONS-OFDIALOGUE-INNARRATIVE-FILM.html>

Sitcom. How Stuff Works. Online document. 7 May $2014<$ http:/electronics. howstuffworks. com/sitcom.htm> 